\title{
Who is Eresus tristis Kroneberg, 1875 (Aranei: Eresidae)?
}

\section{Кто такой Eresus tristis Kroneberg, 1875 (Aranei: Eresidae)?}

\author{
Yuri M. Marusik ${ }^{1-3}$, Galina N. Azarkina ${ }^{4-5}$ \\ Ю.М. Марусик ${ }^{1-3}$, Г.Н. Азаркина ${ }^{4-5}$
}

\footnotetext{
${ }^{1}$ Institute for Biological Problems of the North, Portovaya Street 18, Magadan 685000, Russia. E-mail: yurmar@mail.ru

${ }^{2}$ Department of Zoology \& Entomology, University of the Free State, Bloemfontein 9300, South Africa.

${ }^{3}$ Zoological Museum, Biodiversity Unit, FI-20014 University of Turku, Finland.

${ }^{4}$ Laboratory of Systematics of Invertebrate Animals, Institute of Systematics and Ecology of Animals, SB RAS, Frunze Street 11, Novosibirsk 630091, Russia. E-mail: urmakuz@gmail.com

${ }^{5}$ Department of Zoology \& Centre for Invasion Biology, University of Venda, Thohoyandou, 0950, South Africa.

${ }^{1}$ Институт биологических проблем Севера, ДВО РАН, Портовая 18, Магадан 685000 Россия.

4 Лабратория систематики беспозвоночных животных, Институт систематики и экологии животных СО РАН, ул. Фрунзе, 11, Новосибирск 630091, Россия.
}

KEY WORDS: Araneae, Asia, distribution, Kazakhstan, species revalidated, spider, type locality, Xinjiang. КЛЮЧЕВЫЕ СЛОВА: Araneae, Азия, распространение, Казахстан, ревалидация вида, паук, типовой локалитет, Синьцзян.

ABSTRACT. The male palp of the holotype of Eresus tristis Kroneberg, 1875, a species considered a junior synonym of $E$. kollari Rossi, 1846, is illustrated. A comparison with the palp of $E$. kollari reveals clear differences, and therefore E. tristis is revalidated. The previously unknown type locality is recognized as southernmost Kazakhstan. All literature records of E. tristis are surveyed, and it seems that records from Eastern Kazakhstan and Xinjiang (China) refer to an undescribed species.

How to cite this article: Marusik Yu.M., Azarkina G.N. 2020. Who is Eresus tristis Kroneberg, 1875 (Aranei: Eresidae)? // Arthropoda Selecta. Vol.29. No.4. P.470-474. doi: 10.15298/arthsel. 29.4.09

РЕЗЮМЕ. Приведены рисунки пальпы голотипа Eresus tristis Kroneberg, 1875 - вида, синонимизированного с E. kollari Rossi, 1846. Сравнение пальп двух видов показало, что E. tristis должен быть ревалидизирован. Определён ранее неизвестный типовой локалитет (южный Казахстан). Приведён обзор всех литературных находок, выявлено, что все находки из Восточного Казахстана и Синьцзяна (Китай) относятся к другому, в настоящее время не описанному виду.

\section{Introduction}

Eresus Walckenaer, 1805 is a genus with 22 named species. The genus is known only from the Palaearctic and occurs from the Iberian Peninsula to the Maritime Province of Russia. Although males of the genus are very colorful and conspicuous, Eresus has never been the subject of a widescale revision; however, species from Central Europe [Řezáč et al., 2008; Kovács et al.,
2015], Iran, Turkey [Zamani et al., 2020] and the Soviet Union [Nenilin, Pestova, 1986] have been revised. All species reported and/or described from the territory of the Soviet Union were synonymized with $E$. niger (Petagna, 1787), a species now considered as a nomen dubium [WSC, 2020], and all records of $E$. niger are currently considered to refer to E. kollari Rossi, 1846. So far, three species of Eresus have been described from the Asian part of either the Russian Empire or Soviet Union: E. arenarius Kroneberg, 1875, E. tristis Kroneberg, 1875 and E. niger bifasciatus Ermolajev, 1937. Eresus arenarius is currently considered as a synonym of Stegodyphus lineatus (Latreille, 1817), and E. niger bifasciatus is no longer considered a subspecies but rather E. bifasciatus [Azarkina, Trilikauskas, 2012; WSC, 2020]. Females of all species are similar in appearance, nearly uniformly dark patterned, while males of most species have distinct, contrasting patterns on the abdomen. The most common pattern in males is a dorsally red abdomen with several pairs of black dots. The shape of the male palp is rather uniform, and at the first look can appear to be of the same shape. Nenilin \& Pestova [1986] concluded that the shape of the male palp and the abdominal pattern are highly variable, although their reasoning is unclear. They synonymized with $E$. niger all species from the Asian part of the USSR, including E. tristis, whose male has a uniformly-coloured abdomen.

We recently had the opportunity to examine the holotype male of $E$. tristis and realized that it has distinct differences in the shape of the conductor compared to species occurring in Europe and currently considered as E. kollari (sensu Řezáč et al. [2008]). Based on this, we remove it from the synonymy of $E$. kollari. Additionally, we conducted research to found 

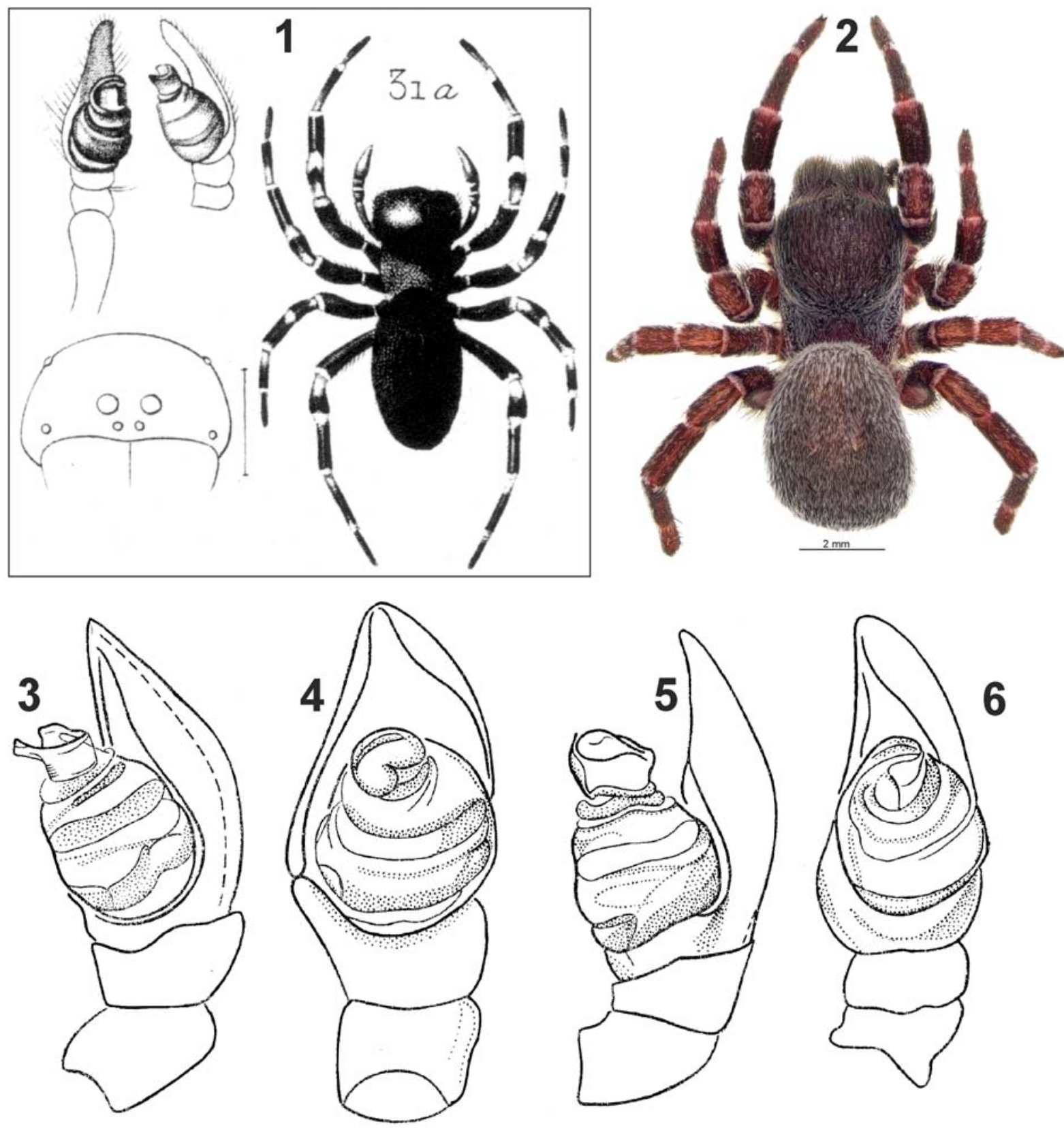

Figs 1-6. Eresus tristis (1, 5-6), Eresus sp. (2) and E. kollari (3-4): 1 - original figures by Kroneberg [1875] showing male habitus (dorsal), palp (ventral and retrolateral), and carapace (frontal); 2 - male from Eastern Kazakhstan, legs lacking white annulations; 3,5 male palp, retrolateral; 4, 6- same, ventral. 3-6 - after Nenilin \& Pestova [1986]; 2 - courtesy of A.A. Fomichev.

Pис. 1-6. Eresus tristis (1, 5-6), Eresus sp. (2) и E. kollari (3-4): 1 - оригинальные рисунки Кронеберга [1875], габитус самца (дорсально), пальпа (вентрально и ретролатерально) и карапакс (спереди); 2 - габитус самца из Восточного Казахстана, ноги без белых колец; 3, 5 - пальпа самца, ретролатерально; 4, 6 - то же, вентрально. 3-6 - из Ненилина и Пестовой [1986]; 2 - фото А.А. Фомичёва.

the exact distribution to find the exact type locality which is not specified in Kroneberg [1875] or subsequent publications.

\section{Eresus tristis Kroneberg, 1875}

Figs 1, 5-10, 14.

E. tristis Kroneberg, 1875: 44, pl. 4, f. 31a-d $\left(\mathrm{O}^{7}\right)$.
E. tristis: Simon, 1895: $331\left(0^{\top}\right.$, reported from Xinjiang, and briefly described, seems misidentified and most likely refers to an undescribed species).

E. tristis: Spassky, Shnitnikov, 1937: 269 (O', reported from Kazakhstan, without precise locality and briefly described, seems misidentified and referring to an undescribed sibling species).

E. niger: Nenilin, Pestova, 1986: 1734, f. 3-4 ( $\odot^{7}$, illustrated holotype of E. tristis and synonymized with E. niger). 

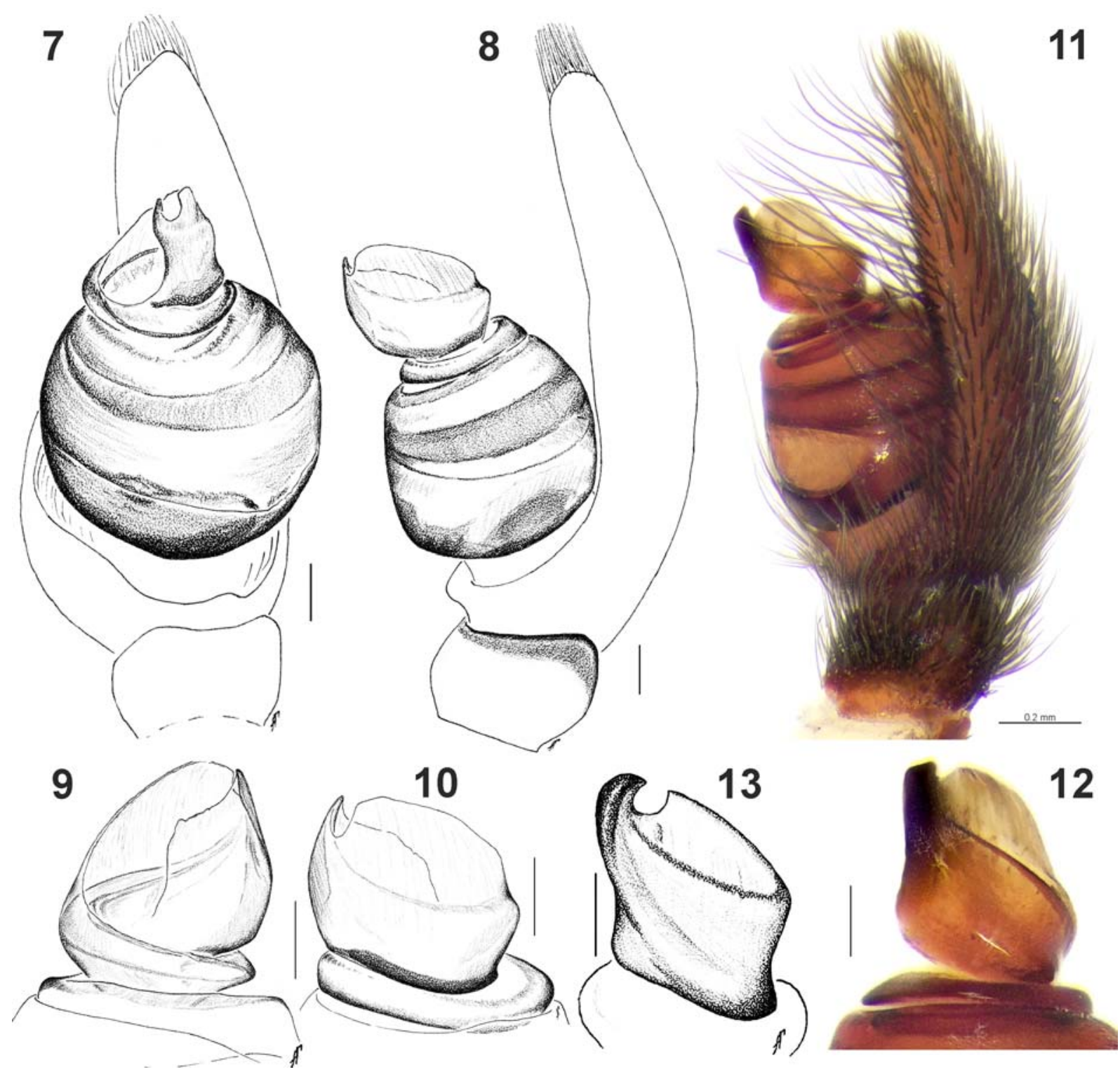

Figs 7-13. Male palps of the holotype of Eresus tristis (7-10), Eresus sp. from Eastern Kazakhstan (11-12) and E. kollari (13): 7 ventral; 8, 11 - retrolateral; 9 - embolic division, prolateral; 10, 12, 13 - same, retrolateral. 11-12 - courtesy of A.A. Fomichev; $13-$ after Azarkina \& Trilikauskas [2012], species probably undescribed [Zamani et al., 2020]. Scale bars: $0.1 \mathrm{~mm}$.

Рис. 7-13. Пальпы самцов голотипа Eresus tristis (7-10), Eresus sp. из Восточного Казахстана (11-12) и E. kollari (13): 7 вентрально; 8, 11 - ретролатерально; 9 - эмболюсный отдел, пролатерально; 10, 12, 13 - то же, ретролатерально. 11-12 фото А.А. Фомичёва; 13 - из Azarkina \& Trilikauskas [2012], изображение относится к неописанному виду [Zamani et al., 2020]. Масштаб 0,1 мм.

Misidentifications:

E. tristis: Wang, 1994: 12, f. 4-6 ( $\sigma^{7}$, no precise locality in Xinjiang, male abdomen with red/black pattern).

E. tristis: Song et al., 1999: 74, f. 31C-D ( $\sigma^{7}$, copy of the figs from Wang [1994]).

TYPE. Holotype $\sigma^{7}$ with the label "Та-1104. Голотип самец, Туркестанская Учёная Экспедиция Императорского Общества Любителей Естествознания. Федченко. 26. Сырдарья, конец апреля" [museum number Ta-1104. Holotype male, Turkestan Scientific Trip of the Emperors Society of the Devotees of Natural History. Fedchenko. 26. Syrdarya [river]. end of April].

COMPARATIVE MATERIAL. Eresus sp. (Figs 2, 11-12): $1 \sigma^{7}$ (ISEA), KAZAKHSTAN, Almaty Region, environs of railway station Saykan $\left(46^{\circ} 26^{\prime} \mathrm{N}, 80^{\circ} 41^{\prime} \mathrm{E}\right)$, sandy steppe, $400 \mathrm{~m}, 15.04 .2016$ (A.A. Fomichev, R.Yu. Dudko \& A.N. Nakonechnyi). Eresus kollari (Fig. 13): $2 \sigma^{7} \sigma^{7}$ (ISEA), RUSSIA, Altai Territory, Barnaul, near Yuzhnyi $\left(53^{\circ} 14^{\prime} \mathrm{N}, 83^{\circ} 38-44^{\prime} \mathrm{E}\right)$ garden, 20.05.2000, 8.08.2020 (G.N. Azarkina). According to Zamani et al. [2020], it belongs to an undescribed species.

TYPE LOCALITY. The exact type locality is not indicated on the label or in the text of Kroneberg's [1875] paper. The label with the holotype male indicates "end of April, Syrdarya [river]". Fedchenko's expedition crossed the river several times, but unfortunately in the description of the expedition [Fedchenko, 1950] the exact days are mentioned 


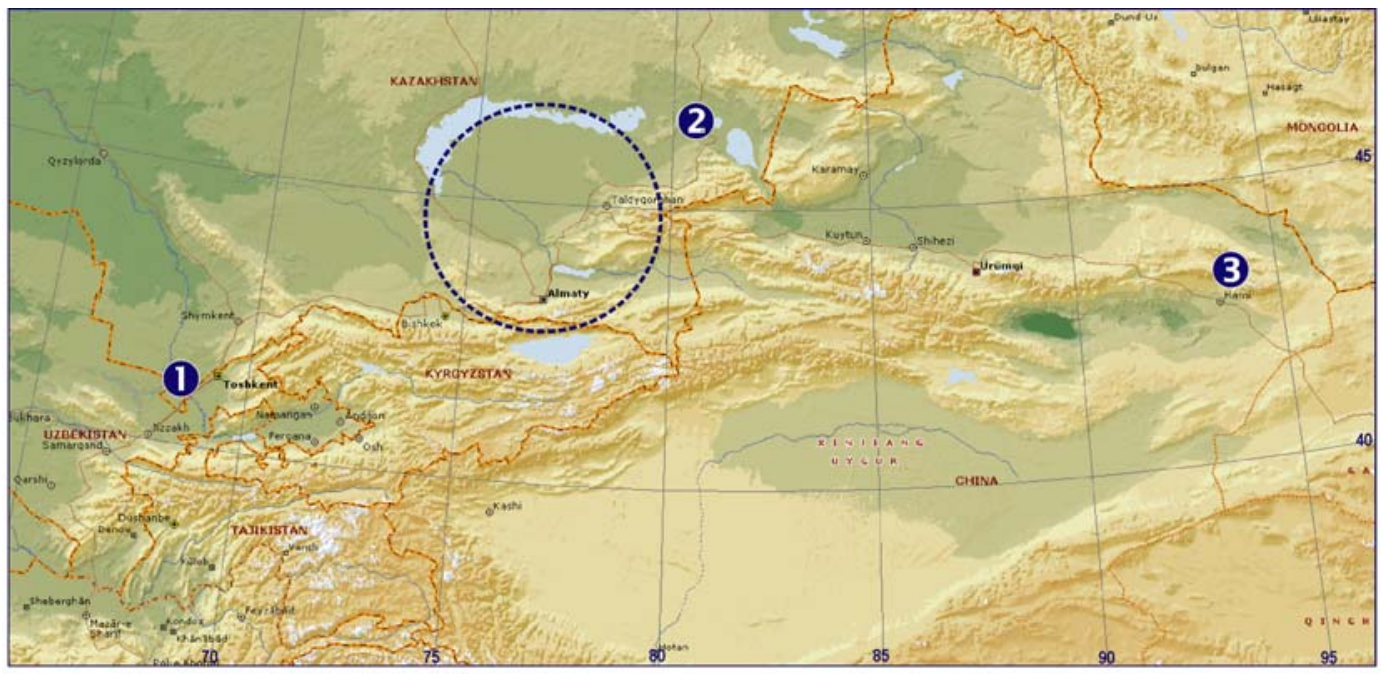

Fig. 14. Map showing published records of Eresus tristis (1, 3) and Eresus sp. (2) from Eastern Kazakhstan: 1 - type locality; 3 record from Simon [1895]; broken line refers to unspecified records from Spassky \& Shnitnikov [1937].

Рис. 14. Точки находок Eresus tristis $(1,3)$ и Eresus sp. (2) из Восточного Казахстана: 1 — типовой локалитет; 3 - из работы Симона [1895]; пунктирная линия — регион где был собран самец, указанный Спасским и Шнитниковым [1937].

only a few times. Thanks to colleagues, we located a diary separately published by Fedchenko (details of the publication is unknown). Fedchenko travelled west of Tashkent in April 1871, and the specimen was collected near Chardara (now Shardara, $\sim 41^{\circ} 14^{\prime} \mathrm{N} 68^{\circ} 01^{\prime} \mathrm{E}$ ), an area located near the Syr Darya River in the Turkestan Region of Kazakhstan.

COMMENTS. The holotype (studied briefly, currently on loan, and not available for detailed study) is faded. Kroneberg [1875] mentioned its length as $7.5 \mathrm{~mm}$, leg I $7.5 \mathrm{~mm}$, leg IV $8.5 \mathrm{~mm}$, and considered the species very similar to $E$. cinnaberinus (Olivier, 1789), differing in the uniformly black abdomen (without any red setae) and the legs with distinct white annulations (cf. Fig. 1). He did not find any differences in the palp and thought it might be a potential synonym of E. cinnaberinus.

Nenilin \& Pestova [1986] examined and illustrated the holotype of E. tristis. Although it differs from the specimen identified as E. niger (Petagna, 1787) by the shape of the conductor, the width of the anterior part of the cymbium (cf. Figs 3-4 and 5-6) and the abdominal pattern, the two names were nevertheless synonymized.

Examination of the male palps of the holotype of $E$. tristis and specimens identified as E. kollari from the Altai revealed distinct differences in the shape of the conductor. These differences are as much as those occurring among well studied species occurring in Europe (cf. Nentwig et al., 2020).

Initially, we had considered the specimen from Eastern Kazakhstan with a uniformly black abdomen to belong to $E$. tristis, but detailed examination of this specimen reveals that it differs from this species in the shape of the conductor as well as the leg coloration.

It seems that there are more than one species of Eresus whose males have a uniformly black abdomen. Besides the specimen from Eastern Kazakhstan illustrated in this paper, a species in Iran also has a uniformly black abdomen but differs from other species by the shape of the conductor [Zamani et al., 2020].
Acknowledgements. We are indebted to Alexander A. Fomichev (Barnaul, Russia) for providing figures of the species similar to Eresus tristis; Anna A. Nekhaeva, Boris A. Korotyaev, B.M. Kataev (St.-Petersburg, Russia) for the information about specimens of E. tristis in the Zoological Institute and help with obtaining the diary of Fedchenko's trip; Kirill G. Mikhailov (Moscow, Russia) for allowing us to study the holotype of E. tristis; Alireza Zamani (Turku, Finland) for consultations about Eresus in Iran and correcting English of the earlier draft; Seppo Koponen and Ilari E. Sääksjärvi (Turku, Finland) who arranged the stay of both authors in Turku. We thank reviewers Alireza Zamani and Alexander A. Fomichev for their critical comments and suggestions. English of the final draft was kindly checked by Sarah Crews (San Francisco, USA). This work was partly supported for GA by the Federal Fundamental Scientific Research Programme for 2013-2020 (No. AAAA-AA16116121410121-7).

\section{References}

Azarkina G.N., Trilikauskas L.A. 2012. Spider fauna (Aranei) of the Russian Altai, part I: families Agelenidae, Araneidae, Clubionidae, Corinnidae, Dictynidae and Eresidae // Euroasian Entomological Journal. Vol.11. No.3. P.199-208.

Fedchenko A.P. 1950. [Voyage in Turkestan]. Moscow: Geografgiz. 467 p., 3 maps [in Russian].

Kovács G., Prazsák I., Eichardt J., Vári G., Gyurkovics H. 2015. A new ladybird spider from Hungary (Araneae, Eresidae) // ZooKeys. Vol.494. P.13-30.

Kroneberg A. 1875. [Voyage of A.P. Fedchenko in Turkestan. Araneae] // Izvestiya Obshchestva Lyubitelei Estestvoznaniya, Antropologii i Etnografii. Vol.19. No.3. P.i-iv, 1-55, pl. 1-5. [in Russian].

Nenilin A.B., Pestova M.V. 1986. [Spiders of the family Eresidae in the fauna of the USSR] // Zoologicheskiy Zhurnal. Vol.65. No.11. P.1734-1736 [in Russian].

Nentwig W., Blick T., Bosmans R., Gloor D., Hänggi A., Kropf C. 2020. Spiders of Europe. Version 09.2020. Online at https:// www.areneae.unibe.ch, accessed on 10 September 2020. 
Rezáč M., Pekár S., Johannesen J. 2008. Taxonomic review and phylogenetic analysis of Central European Eresus species (Araneae: Eresidae) // Zoologica Scripta. Vol.37. No.3. P.263-287.

Simon E. 1895. Arachnides recueillis par M. G. Potanine en Chinie et en Mongolie (1876-1879) // Bulletin de l'Académie impériale des sciences de St.-Pétersbourg. Ser.5. Vol.2. No.4. P.331345.

Song D.X., Zhu M.S., Chen J. 1999. The spiders of China. Shijiazhuang: Hebei Science and Technology Publishing House. 640 pp.

Spassky S.A., Shnitnikov V.N. 1937. [Materials to the spder fauna of Kazakhstan] // Pavlovksi E.N. (ed.). Materialy po vreditelyam zhyvotnovodstva i faune preimushchestvenno Yuzhnogo Kazakhstana. Trudy Kazakhstanskogo filiala AN SSSR. Mos-
cow-Leningrad. AN SSSR Publ. House. No.2. P.265-300 [in Russian].

Wang J.F. 1994. Two species of spiders of the genus Eresus from China (Araneae: Eresidae) // Journal of Hebei Normal University (Nat. Sci. Ed.) 1994 (Suppl.). P.11-13.

WSC. 2020. World Spider Catalog. Natural History Museum Bern, Bern. Available from: http://wsc.nmbe.ch (accessed on $10 \mathrm{Sep}-$ tember 2020).

Zamani A., Altýn C., Szüts T. 2020. A black sheep in Eresus (Araneae: Eresidae): taxonomic notes on the ladybird spiders of Iran and Turkey, with a new species // Zootaxa. Vol.4851. No.3. P.559-572.

Responsible editor K.G. Mikhailov 